\title{
The impact of monetary policy on household consumption in South Africa: Evidence from vector autoregressive techniques
}

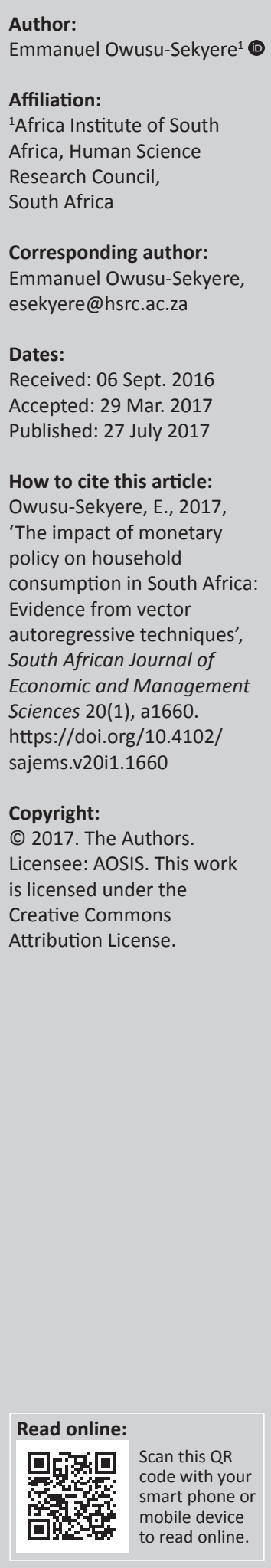

Background: This article adds to scarce sub-Saharan African and South African literature on monetary policy transmission mechanisms by looking into: (1) the Keynesian interest rate channel of monetary policy transmission in South Africa, focussing on the behaviour of household credit and household consumption; (2) using the time-varying parameter vector autoregressive (VAR) techniques with stochastic volatility to capture the time-varying nature of the underlying structure of the South African economy to see whether it performs better than the constant parameter VAR in so doing and (3) policy implications emerging from the findings of the study.

Aim: In testing the hypotheses of the interest rate channel of monetary policy transmission, the aim is to see how household credit and ultimately household consumption have evolved in South Africa: (1) before inflation targeting (1994-1999), (2) after inflation targeting (2000-2007) and (3) during the global financial crisis (2007-2012) in response to different monetary policy positioning.

Setting: We focus on three periods: post transition from apartheid, during inflation targeting and during the global financial crisis, periods which saw changes in the monetary policy stance in South Africa.

Methods: Quarterly data from 1994Q1 to 2012Q4, constant parameter VAR and time-varying parameter vector autoregressive (TVP-VAR) techniques are used in this study. The use of the TVP-VAR is to capture the time-varying nature of the underlying structure of the South African economy and also to investigate whether it performs better than the constant parameter VAR in so doing.

Results: The results show that household credit and consumption declined and stayed negative post transition and after inflation targeting - periods of monetary tightening in South Africa - but increased during the global financial crisis, which saw expansionary monetary policy measures aimed at mitigating the negative output gap in South Africa.

Conclusion: These changes in household credit and consumption across the different time periods show evidence of the cost of credit effect of monetary policy on household consumption in South Africa. They further reflect the impact of different structural changes and exogenous shocks on monetary policy conduct in South Africa and its pass through effect on household consumption in South Africa. We further conclude that the time TVP-VAR with stochastic volatility performs better than the constant parameter VAR in capturing the time-varying nature of the underlying structure of the South African economy.

\section{Introduction}

The transmission mechanism of monetary policy has received enormous theoretical and empirical attention in macroeconomic literature. The aim has been to establish how a shock to a key monetary policy tool impacts on interest rates, exchange rates, inflation, output and other macroeconomic variables. Monetary policy is transmitted via a number of channels through the macroeconomy. The transmission mechanisms of monetary policy include the interest rate channel, exchange rate channel, asset price effects and the credit channel (Mishkin 1995).

Interest rates play a key role in most of the channels of monetary policy transmission. The interest rate channel of monetary policy transmission basically states that, keeping all else unchanged, a

Note: This article is partially based on the author's Economic Research Southern Africa (ERSA) working paper 598, 'The impact of monetary policy on household consumption in South Africa: Evidence from Vector Autoregressive Techniques', 18 April 2016, available here: https://econrsa.org/system/files/publications/working_papers/working_paper_598.pdf 
change in monetary policy, whether contractionary or expansionary, impacts on real short-term interest rates which in turn affects the cost of capital, investment spending, aggregate demand and ultimately the level of output. Thus, a contractionary monetary policy, for instance, would mean an increase in the policy tool [repurchase rate (repo) in South Africa], leading to a rise in short-term real interest rates, raising the cost of capital which results in a fall in investment spending. Aggregate demand falls and output falls. On the contrary, expansionary monetary policy would mean a reduction in the repo rate leading to a fall in real short-term interest rates, lower cost of capital, a boost to investment spending, aggregate demand and ultimately the level of output (Mishkin 1995).

The hypothesis this article seeks to test is the traditional Keynesian interest rate channel of monetary policy transmission in South Africa, for a number of reasons. The monetary policy committee of South Africa's Reserve Bank (SARB) has had to increase the repo rate on three consecutive occasions in less than a year, between July 2015 and March 2016. The aim is to reign in inflationary pressures generated by $13 \%$ depreciation of the South African Rand since January 2015. Core inflation is forecast to hit 5.5\% in 2016 and 5.4\% in 2017 if the current prevailing macroeconomic circumstances pertain (SARB 2015). Adverse climate change effects on food production have also led to South Africa to import staple food to subsidise the shortages in domestic food production. Coupled with the weak Rand, this is likely to further fuel import induced inflation and also worsen the current account balance. On the demand side, household consumption expenditure is expected to remain muted as higher personal income taxes, the effect of the Rand's depreciation and higher interest rates, kick in. The stalling household consumption expenditure is further reflected in credit to households because consumption in South Africa is highly driven by credit. Growth in credit extension to households in Q1 2015 was 10.6\% below credit to firms. The interest rate hikes by the SARB imply that the cost of servicing existing debt increases coupled with a higher cost of acquiring new debt by households.

Against this background of a depreciating Rand, increasing inflation and interest rate hikes, this article seeks to investigate the interest rate channel of monetary policy transmission in South Africa. We focus on three periods: post political transition, after inflation targeting and during the global financial crisis. These three periods each saw a distinctly different monetary policy stance. In the process, we focus on how household credit and household consumption behaved during these three different periods. Although the original Keynesian theory on the cost of credit focussed on business investment spending, later research has shown that consumption of durables goods and household residential expenditure are equally investment decisions (Mishkin 1995). Wilcox (1990) also found that nominal interest rates are relevant in explaining both durable and non-durable household consumption.
The rest of this article is structured as 'Relevant literature', 'Empirical methodology', 'Data', 'Empirical results' and 'Conclusion'.

\section{Relevant literature}

Studies on the transmission mechanism of monetary policy mostly employ the canonical vector autoregressive approach proposed by Sims (1980). Notable among these are Bernanke and Gertler (1995) who looked at the credit channel of monetary policy transmission in the United States; Mishkin (1995) examined various channels of monetary transmission mechanisms; Kim and Roubini (2000) for the G7 countries, and Christiano, Eichenbaum and Evans (1999) for the United States. The vector autoregressive framework by Sims (1980) used in these studies assumes time-varying coefficients but constant volatility of the disturbances. Hence it has been found to fail to capture structural changes underlying the macroeconomy. Consequently, recent research (Franta, Horvath \& Rusnak 2011 on the Czech Republic; Nakajima 2011 on Japan) has seen the use of the time-varying parameter vector autoregressive (TVP-VAR) with stochastic volatility proposed by Primiceri (2005) to capture the time-varying nature of the underlying structure of economies. To control for the structural changes underlying the data generating process, it is assumed that the parameters in the TVP-VAR specification follow a first-order random walk. This allows for the capture of both temporary and permanent changes in the parameters. The concept of stochastic volatility was initially proposed by Black (1976) and later used in macroeconomic research (Cogley \& Sargent 2001; Primiceri 2005; Uhlig 1997) as well as in financial economic research (Ghysels, Harvey \& Renault 2002; Shephard 2005).

The TVP-VAR algorithm is well suited to this study for a number of reasons. Firstly, the monetary policy framework in South Africa has been through various institutional changes. As expected, these institutional changes would have different effects over time on economic outcomes in South Africa ${ }^{1}$. Secondly, there have been several structural shocks and global financial developments over the sample period. Three periods within the sample period are considered; after the political transition from 1994 to 1999 , the inception of inflation targeting from 2000 onwards and during the global financial crisis from 2007 onwards. The period after the political transition posed significant challenges to monetary policy conduct in South Africa. There was first a massive capital flight out of South Africa prior to the political transition. Post transition, South Africa's capital markets were liberalised, increasing the level of integration with global financial markets. Exchange controls were relaxed, and the financial sector deepened as financial service providers began to extend financial access to previously excluded households who were in the majority (Smal and de Jager 2001). These new economic developments led to high inflation and interest rates (Smal and de Jager 2001). South Africa then adopted inflation targeting in 2000, after which the rate of inflation

1.See Smal and de Jager (2001) for details on the different regimes of monetary policy in South Africa. 
was largely kept within the target range of $3 \%-6 \%$ as a result of a macroprudential and more forward looking approach to monetary policy. The period of the global financial crisis saw low global inflation and low demand for exports from resource endowed and commodity exporting countries like South Africa. This led to softening commodity prices, declining export revenues and a sharp depreciation of the currencies of such countries. South Africa's current account balance as a ratio to gross domestic product (GDP) worsened from a deficit of $-2.7 \%$ of GDP in 2009 to $-5.4 \%$ of GDP at the end of 2014 (SARB 2014). On the domestic front, labour stoppages in key sectors of South Africa's economy and demand for above inflation wages led to falls in productivity, increases in per unit cost of labour and declines in export volumes. The rate of inflation in South Africa was forecasted to push close to the upper range of the inflation target $(6 \%)$ in 2014 and 2015. This further led to corresponding increases in lending rates of banks (SARB 2012). Figure A1 illustrates these trends in GDP growth, rate of inflation, lending rate and the current account deficit as percentage of GDP as discussed above. These diverse structural and external shocks across the sample period make it clear that macroeconomic shocks can be generated from different sources, exogenous and endogenous, at different times and simultaneously. This confirms the time-varying nature of the underlying structure of the South African economy. Consequently, the varying volatility of shocks and their attendant varying size effects is the motivation for using the TVP-VAR model which is known to be more suitable compared to constant parameter VAR estimation under such circumstances (Nakajima 2011)

Furthermore, the focus of existing literature on monetary transmission mechanisms has mainly been on developed countries and, to a much lesser extent, low-income countries or sub-Saharan Africa to be specific. In some of these sub-Saharan African studies using vector autoregressive approaches with both recursive and structural identification, it has been difficult to establish evidence of monetary policy transmission mechanisms or any impact of monetary policy innovations on aggregate demand or output. Mishra and Montiel (2012) reviewed a number of such publications to assess the effectiveness of monetary policy transmission mechanisms in low-income countries. In sub-Saharan African countries, a weak and unreliable monetary transmission dominated by the banking or credit channel was found. Saxegaard (2006) compared the effects of monetary policy innovations in Nigeria, Uganda and CEMAC $^{2}$ countries under two monetary policy scenarios; one with banks holding excess reserves and the other in which banks held no excess reserves. For Nigeria and Uganda, Saxegaard (2006) found weak effects of monetary policy on output and inflation in the scenario in which banks held excess reserves. Monetary policy innovations had a stronger impact on inflation and output under the scenario in which banks had no excess reserves. For CEMAC countries, monetary policy

2.CEMAC means Central African Economic and Monetary Community. It consists of six member countries, namely: Gabon, Cameroon, the Central African Republic (CAR) Chad, the Republic of the Congo and Equatorial Guinea. innovations had weak effects on aggregate demand indicators under both scenarios. On the contrary, Cheng (2006) found a statistically significant effect of monetary policy innovations on the level of prices but no effect on output in Kenya. In Ghana, Abradu-Otoo, Amoah and Bawumiah (2003), using generalised impulse responses, could not find any effects of monetary policy shocks on aggregate demand or output. These findings for some sub-Saharan African countries have largely been attributed to underdeveloped financial sectors and poor institutional environment, which restrict lending activity or mute the impact of monetary policy innovations on economic stabilisation.

Unlike most sub-Saharan African countries, South Africa has a well-developed financial sector. Consequently, it is expected that monetary policy innovations would have the anticipated effect on aggregate demand indicators and output. Aron and Muellbauer (2002) used a multistep forecasting technique to predict output growth in South Africa, taking into consideration several factors including monetary policy regime shifts in the 1980s in South Africa. They found that real interest rates impact on output in South Africa with the effects persisting for 3 years. Gumata, Kabundi and Ndou (2013) used a large Bayesian vector autoregressive model to investigate the relevance of different monetary policy transmission channels in South Africa from 2001 to 2012. They found that for the interest rate channel, there was evidence of changes in the repo rate impacting on short-term interest rates, the cost of capital and therefore investment spending by corporates and households, and consequently the level of output. A more recent study on South Africa is by Du Plessis, Smit and Steinbach (2014), which compared the efficacy of dynamic stochastic general equilibrium models (DGSE) as a potential forecasting tool for consumer price index (CPI) and growth to other private sector consensus approaches. Du Plessis et al. (2014) found that the dynamic stochastic general equilibrium (DSGE) models outperform the private sector models especially over longer horizons, whereas the private sector models outperformed the DSGE model in the near term as forecasting tools for CPI inflation and growth.

These studies on sub-Saharan Africa and more specifically South Africa have looked mainly at the channels of monetary transmission or the impact of a monetary policy shock on inflation, interest rates, exchange rates and aggregate level of output. The response of a specific component of aggregate demand to a monetary policy shock has not been given adequate attention in the sub-Saharan African literature. Bernanke and Gertler (1995), looking at the credit channel of monetary policy transmission in the United States, found that inconsistencies with theory emerge when output or aggregate demand is decomposed into its interest sensitive components. There were differences in the magnitude, timing and composition of spending effects. Long lived assets, such as residential investment and consumption of durables which should respond to real long-term rates, equally responded to monetary policy shocks, which ideally impacts on short-term rates (Bernanke and Gertler 1995). Again, in the monetary policy literature on sub-Saharan Africa, there is very little 
evidence of the use of TVP-VAR. One such study is Mwabutwa, Bittencourt and Viegi (2013) on Malawi (unpublished). Other papers that have used TVP-VAR looked at other issues such as the impact of house and stock prices on consumption (Peretti, Gupta \& Inglesi-Lotz 2012) and the impact of house prices on interest rates (Aye, Gupta \& Modise 2013).

This article, therefore, adds to scarce sub-Saharan African literature by looking into: (1) the Keynesian interest rate channel of monetary policy transmission in South Africa, focussing on the behaviour of household credit and household consumption; (2) using the TVP-VAR with stochastic volatility by Primiceri (2005) to capture the time-varying nature of the underlying structure of the South African economy and whether it performs better than the constant parameter VAR in so doing; and (3) policy implications emerging from the findings of the study. In testing the hypotheses of the interest rate channel of monetary policy transmission, the aim is to see how household credit and ultimately household consumption have evolved in South Africa: (1) before inflation targeting (1994-1999), (2) after inflation targeting (2000-2007) and (3) during the global financial crisis (2007-2012) in response to different monetary policy positioning.

\section{Empirical methodology}

The TVP-VAR model evolves from a basic structural VAR model specified as:

$A y_{t}=\prod_{1} y_{t-1}+\ldots . .+\prod_{s} y_{t-s}+\mu_{t^{\prime}} t=s+1, \ldots, n$

[Eqn 1]

where $y_{t}$ is a $k \times 1$ vector of observed variables, and $A, \prod_{1 t} \ldots, \Pi_{s t}$ are $k \times k$ matrices of coefficients. The disturbance term $\mu_{t}$ is a $k \times 1$ structural shock assumed to be $\mu_{t} \sim N(0, \Sigma)$, where:

$\Sigma=\left[\begin{array}{cccc}\sigma_{1} & 0 & \cdots & 0 \\ 0 & \ddots & \ddots & \vdots \\ \vdots & \ddots & \ddots & 0 \\ 0 & \cdots & 0 & \sigma_{k}\end{array}\right]$

The simultaneous relations of the structural shock are specified by recursive identification, assuming that $A$ is a lower triangular matrix with diagonal elements equal to one:

$$
A=\left[\begin{array}{cccc}
1 & 0 & \cdots & 0 \\
a_{21} & \ddots & \ddots & \vdots \\
\vdots & \ddots & \ddots & 0 \\
a_{k 1} & \cdots & a_{k, k-1} & 1
\end{array}\right]
$$

Equation 1 is re-specified as a reduced from VAR model defined as follows:

$y_{t}=B_{1} y_{t-1}+\ldots . .+B y_{s-s}+A^{-1} \sum \varepsilon_{t^{\prime}} \varepsilon_{t} \sim N\left(0, I_{k}\right)$,

[Eqn 2]

where $B_{i}=A^{-1} \prod_{i}$, for $i=1, \ldots s$. Stacking the elements in the rows of the $B_{i}^{\prime}$ s to form $\beta\left(k^{2} s \times 1\right)$ vector and defining
$X_{t}=I_{k} \otimes\left(y_{t-1}^{\prime}, \ldots . . y_{t-s}^{\prime}\right)$ where $\otimes$ denotes the Kronecker product. We can re-write Equation 2 as:

$y_{t}=X_{t} \beta+A^{-1} \sum \varepsilon_{t}$

[Eqn 3]

All the parameters in Equation 3, $\beta, A$ and $\Sigma$ are timeinvariant. To extend this to a TVP-VAR, the parameters must be allowed to change over time. Following Nakajima (2011) and Primiceri (2005), Equation 3 can be re-defined in a TVPVAR specification as follows:

$y_{t}=X_{t} \beta_{t}+A_{t}^{-1} \Sigma_{t} \varepsilon_{t} t=s+1, \ldots n$

[Eqn 4]

where the coefficients $\beta_{t^{\prime}} A_{t}$ and $\Sigma_{t}$ are all time-varying. Following Primiceri (2005), to model the process for these TVPs, let $\alpha_{t}=\left(\alpha_{21^{\prime}}, \alpha_{31}, \alpha_{41}, \ldots . . \alpha_{k, k-1}\right)^{\prime}$ be a stacked vector of lower triangular elements in $A_{t^{\prime}}$ and $h_{t}=\left(h_{1 t^{\prime}}, \ldots, h_{k t}\right)$, where $h_{j t}=\log \sigma_{j t}^{2}$ for $j=1 \ldots, k, t=s+1, \ldots n$. It is assumed that the TVPs in Equation 4 follow a first-order random walk process, where $\beta_{t+1}=\beta_{t}+\mu_{\beta t^{\prime}} \alpha_{t+1}=\alpha_{t}+\mu_{\alpha t^{\prime}} h_{t+1}=h_{t}+\mu_{h t^{\prime}}$ :

$\left[\begin{array}{c}\varepsilon_{t} \\ \mu_{\beta t} \\ \mu_{\alpha t} \\ \mu_{h t}\end{array}\right] \sim N\left[0,\left[\begin{array}{cccc}I & 0 & 0 & 0 \\ 0 & \Sigma_{\beta} & 0 & 0 \\ 0 & 0 & \Sigma_{\alpha} & 0 \\ 0 & 0 & 0 & \Sigma_{h}\end{array}\right]\right]$

for $t=s+1, \ldots, n$,

where:

$\beta_{s+1} \sim \mathrm{N}\left(\mu_{\beta 0}, \sum_{\beta 0}\right), \alpha_{s+1} \sim \mathrm{N}\left(\mu_{\alpha 0}, \sum_{\alpha 0}\right), \mathrm{h}_{s+1} \sim \mathrm{N}\left(\mu_{h 0}, \sum_{h 0}\right)$.

Allowing all parameters to vary over time causes an overidentification problem and makes the likelihood function intractable and the model difficult to estimate (Nakajima 2011; Peretti et al. 2012). Stochastic volatility also raises the possibility of overparameterisation, which impedes precise estimation of the parameters and impulse responses (Koop and Korobilis 2010). Consequently, the TVP-VAR is estimated using the Markov Chain Monte Carlo (MCMC) methods. The MCMC algorithm avoids the issue of dimensionality and helps to mitigate over-identification or parameter explosion and nonlinearities in the relationships between economic variables emanating from the assumption that all the parameters in the TVP-VAR follow a first-order random walk process (Banerjee and Malik 2012). Furthermore, the essence of the MCMC method is to assess the joint posterior distributions of the parameters of interest based on set prior probability densities within a Bayesian inference. Flat priors are set for the initial stage of the TVP-VAR such that $\mu_{\beta 0}=\mu_{\alpha 0}=$ $\mu_{h 0}=0$ and $\Sigma_{\beta 0}=\Sigma_{\alpha 0}=\Sigma_{h 0}=10 \times I$. Flat priors are set based on the assumption that we have no prior information about the South African economy. Unlike in Nakajima (2011) which follows Primiceri (2005), we do not set our priors based on the estimates of the constant parameter VAR. The two estimation approaches are kept mutually exclusive of each other. The essence is to test whether the TVP-VAR performs better compared to the unrestricted constant parameter VAR 
with a few exogenous control variables in capturing the underlying structural changes in the fundamentals of the South African economy. In the estimation, $\mathrm{M}=10000$ samples are drawn discarding the initial 1000 samples. The Geweke $(1992)^{3}$ convergence diagnostics (CD) and inefficiency factors are used to establish whether the posterior means converge to the posterior distribution. If the CD statistic is less than 1 and the inefficiency factors are less than 100 , we fail to reject the null of convergence to the posterior distribution. This is done at $95 \%$ credible intervals ${ }^{4}$ and $5 \%$ level of significance. In this case, the estimated posterior prior mean will be close to the true value of the parameter and will be included in the $95 \%$ credible interval.

\section{Data}

The variables selected for estimation in this article are based on the Keynesian interest rate channel of monetary policy transmission. Quarterly data are used in this article from 1994Q1 to 2012Q4. All variables are from the SARB and International Financial Statistics of the IMF detailed in Appendix $1^{5}$. These are the South African Reserve Bank repurchase rate (repo), real lending rate (rrate), domestic private credit to households (hhcr), and real aggregate household consumption of final goods and services $(h c)$. As detailed in Table A2, the variables are I(1) as per results of the Augmented Dickey-Fuller (1981) ADF test and Phillips-Perron (1988) both with a $H_{0}$ : non-stationarity, and the Kwiatkowski, Phillips, Schmidt-Shin (KPSS) (1992) test which has a $H_{0}$ : stationarity.

The mean, maximum and minimum levels of the repo rate and real lending rate are highest post transition and during inflation targeting and lowest during the global financial crisis. This shows higher levels of monetary tightening post transition and during inflation targeting, than during the crisis. Consequently, the mean, maximum and minimum levels of household credit and household consumption are lowest post transition, during inflation targeting and highest during the period of the crisis (see Table A3). Using the standard deviation as a basic measure of volatility, the inception of inflation targeting (2000-2007) shows the lowest levels of volatility in the repo rate, real lending rate and household credit. Volatility for household consumption is lowest post transition from apartheid and highest post inflation targeting, declining marginally during the global financial crisis. Cross-correlation analysis across the different time periods also shows significant differences

3.In Geweke (1992), a comparison is made between the first $n$ draws and the last $n$ draws. The middle draws are dropped to check for convergence in the Markov Chain. The CD statistic is given by $\mathrm{CD}=\left(\bar{x}_{0}-\bar{x}_{1}\right) / \sqrt{\hat{\sigma}_{0}^{2} / n_{0}+\hat{\sigma}_{1}^{2} / n_{1}}$ where $\bar{x}_{j}=\left(1 / n_{j}\right) \sum_{i=m_{j}}^{m_{j}+n_{j}-1} x^{(i)}$, with $x^{(i)}$ being the $i$-th draw, $\hat{\sigma}_{j}^{2} / n_{j}$ is the standard error of $\bar{x}_{j}$ respectively for $\mathrm{j}=0,1$. The sequence of the MCMC sampling converges to a standard normal distribution if it is stationary. We set $m_{0}=1, n_{0}=1000, m_{1}=5001$ and $\mathrm{n}_{1}=5000 . \hat{\sigma}_{j}^{2}$ is computed using a Prazen window with bandwidth $\left(B_{m}\right)^{2}=500$. The efficiency factor is defined as $1+2 \sum^{B_{m}} \rho_{s}$, where $\rho_{\mathrm{s}}$ is the sample autocorrelation at lag $\mathrm{s}$, which is computed to measure how well the MCMC chain mixes.

4.Bayesian inference uses credible intervals instead of confidence intervals to describe the uncertainty of the parameter. In MCMC analysis, $97.5 \%$ or $2.5 \%$ quartiles of posterior draws are usually reported.

5.See Appendix 1 for details of variables, unit root tests, and descriptive statistics and correlation matrices. (see Table A4a-A4c). The period post transition shows positive correlation between the repo rate, lending rate and household credit and household consumption. This period was mainly characterised by measures to extend financial access to previously excluded households who were in the majority (Smal and de Jager 2001). Thus, other systemic changes that enhanced financial access must have overshadowed the impact of the cost of credit to households and on household consumption. The period post inflation targeting shows evidence of the cost of credit to households as depicted by strong negative correlations between repo and lending rates on one hand and household credit and household consumption on the other hand. There is also a strong positive correlation between household credit and household consumption emphasising the extensive role of credit in household consumption in South Africa. The period during the global financial crisis shows much stronger evidence of the cost of credit to households, evidenced by the negative correlation between the repo rate, real lending rate and household consumption. There is also a lower positive correlation between household credit and household consumption as compared to the preceding period. This could probably be explained by the fact that household incomes were over leveraged by this time as well as the credit crunch that characterised the period of the global financial crisis.

\section{Empirical results}

A VAR(2) model is estimated that examines the impact of the repo rate (repo) on the real lending rate (rrate), private domestic credit to households ( $h$ hcr ) and aggregate household consumption of final goods and services. We consider the timing, direction and duration of the response of household credit and household consumption to a shock to the repo rate. Although the variables are $I(1)$, the estimation of the constant parameter VAR is done with the data in levels as recommended by Sims (1980) and further evidenced by Disyatat and Vongsinsirikul (2003), Eichenbaum (1992). The variables are ordered recursively under the assumption that variables ordered early affect subsequent variables contemporaneously with no feedback effect. The recursive ordering is determined by economic theory, using the traditional Keynesian theory on the interest rate channel of monetary transmission in Mishkin (1995). The repo rate is the monetary policy tool that determines other short-term interest rates at which households borrow for consumption expenditure. Duca (1995) found a strong positive relationship between the availability of consumer instalment loans by banks and various indicators of monetary policy. Cholesky decomposition is then used to factorise the covariance matrix of the VAR model. Thus, the relationship between the reduced form errors and the disturbances become lower triangular. As in Cheng (2006), a non-fuel world commodity price index (Comm) and a world fuel price index (Oil) are used as exogenous variables to control for external shocks in the constant parameter VAR estimation. A wage index (wages) is also used to capture the impact of externally driven supply side factors that have driven structural breaks in South Africa 
over the sample period. Although wage agitations are domestic in nature, factors driving the reasons for above inflation wage demands are largely external, such as the upside risks posed by prevailing global economic trends to the rate of inflation and depreciation of the South African Rand. Thus, the use of a wage index here as an exogenous factor is not the ideal, it is simply a proxy to 'capture the impact of' externally driven supply side factors driving wage agitations in South Africa. This is purely an improvisation solely for the purpose of this article.

An optimal length of two lags determined by the standard lag order selection criteria applied to a constant parameter VAR is used in the estimation (see Table A5 for results of lag order selection results and Table A6 for VAR stability tests). Three out of the five criteria selected 5 lags, while two criteria selected 2 lags as the optimal lag length. Although both 5 lags and 2 lags meet the VAR stability condition (all roots lie within the unit circle) two lags are preferred to 5 lags in the estimation. This is because in the TVP-VAR estimation 2 lags are used. Hence, to ensure consistency with the constant parameter VAR estimation, 2 lags are used for both estimations. The TVP-VAR results in Table 1 give the estimates for the posterior means, standard deviations, 95\% credible intervals, the CD of Geweke (1992) and inefficiency factors computed using the MCMC sample.

The CD statistics are less than unity, and the inefficiency factors are less than 100. Thus, we fail to reject the null hypothesis of convergence to the posterior distribution at $5 \%$ level of significance. The low inefficiency factors show that the MCMC algorithm efficiently produces posterior draws. Additionally, the estimated posterior mean for each parameter falls within their respective $95 \%$ credible intervals. Thus, the estimated posterior means are close to the true value of the parameters.

Figure 1 plots the posterior draws for each data series (top panel) and posterior mean estimates for stochastic volatility of the structural shock (bottom panel). The results show that repo rate volatility peaked sharply in 1998, early 2000s and 2009. These volatility peaks in the repo rate have been attributed to increase in interest rates by the SARB aimed at mitigating capital flow reversals from South Africa emanating from the spill over effect of the Asian crisis in 1997, the global economic aftermath of the 9/11 USA attack and the global financial crisis, respectively. Figure 1 also depicts periods of downward trends in repo rate volatility. Repo rate volatility

TABLE 1: Estimated results of the selected parameters in the time-varying parameter vector autoregressive model.

\begin{tabular}{lccccc}
\hline Parameter & Mean & Standard deviation & 95\% Interval & CD & Inefficiency \\
\hline$\left(\Sigma_{\beta}\right)_{1}$ & 0.0332 & 0.0080 & $0.0217,0.0522$ & 0.227 & 18.07 \\
$\left(\Sigma_{\beta}\right)_{2}$ & 0.0337 & 0.0078 & $0.0221,0.0520$ & 0.293 & 15.72 \\
$\left(\Sigma_{a}\right)_{1}$ & 0.0750 & 0.0287 & $0.0410,0.1487$ & 0.125 & 34.80 \\
$\left(\Sigma_{a}\right)_{2}$ & 0.0490 & 0.0105 & $0.0333,0.0749$ & 0.000 & 18.31 \\
$\left(\Sigma_{h}\right)_{1}$ & 0.1816 & 0.1247 & $0.0612,0.5516$ & 0.310 & 85.17 \\
$\left(\Sigma_{h}\right)_{2}$ & 0.5813 & 0.1908 & $0.2651,0.0189$ & 0.394 & 80.78 \\
\hline
\end{tabular}

$\mathrm{CD}$, convergence diagnostics.

Note: The estimates of $\Sigma_{a}$ and $\Sigma_{\beta}$ are multiplied by 100 . trends downward from 1998 towards the year 2000 as a result of South Africa adopting inflation targeting and the resumption of capital flows back towards emerging markets because of a strong global recovery from the Asian crisis (SARB 1999), from 2004 to 2007 thereabouts because of stronger global economic growth, higher level of domestic output per worker, higher economic growth and declining rate of inflation (SARB 2004). Repo rate volatility then declines from 2009 onwards, staying very low thereafter because of an expansionary monetary policy stance aimed at stimulating economic activity to address the large output gap in South Africa (SARB 2009).

The lending rate volatility closely tracks trends in repo rate volatility, peaking and declining in the same periods as the repo rate before inflation targeting, after inflation targeting and during the global financial crisis for the same reasons as explained above.

Household credit volatility peaks sharply post transition towards 1998. Adequate banking sector liquidity and a declining repo rate led to cheaper cost of credit and an extension of credit (SARB 1998). Household credit volatility after 1998 stays flat and close to zero throughout the inflation targeting period and during the global financial crisis. Among other possible factors, this could be attributed to improvements in the ease of acquiring credit in diverse forms beside direct bank loans for consumption by previously excluded households (Smal and de Jager 2001). Household consumption volatility first reflects the volatility in household credit post transition towards 1998, after which it trends with the volatility patterns in the repo rate and lending rate. The sturdy pace of increase in household consumption post transition was attributable to an increase in all aspects of domestic expenditure post transition despite weak growth, peaking sharply in 1998. Specifically, household consumption of non-durable goods and services was accountable for this upward trend in household consumption, as compared to durable goods and semi durable goods consumption, which declined during this period (SARB 1998). Household consumption volatility again peaks slightly in the early 2000s. Despite the weak global growth, domestic growth in South Africa remained robust. There was an increase in nonagriculture sector employment, increases in salaries and wages and therefore household disposable income (SARB 2002). From 2004 onwards, household consumption volatility moderately trends downwards, staying close to zero after 2010 because of the availability of other forms of credit, increased ease of acquiring debt-financed consumption and consequently overleveraged household disposable income. This is confirmed by the high household debt to disposable income ratio in South Africa (76\%) (SARB 2013).

The increase in diverse forms of credit in 1998 is captured to some extent by trends in household credit over the sample period. This is because in numerous literature on financial inclusion credit to households or the private sector is used as a measure of financial inclusion or access to finance although 


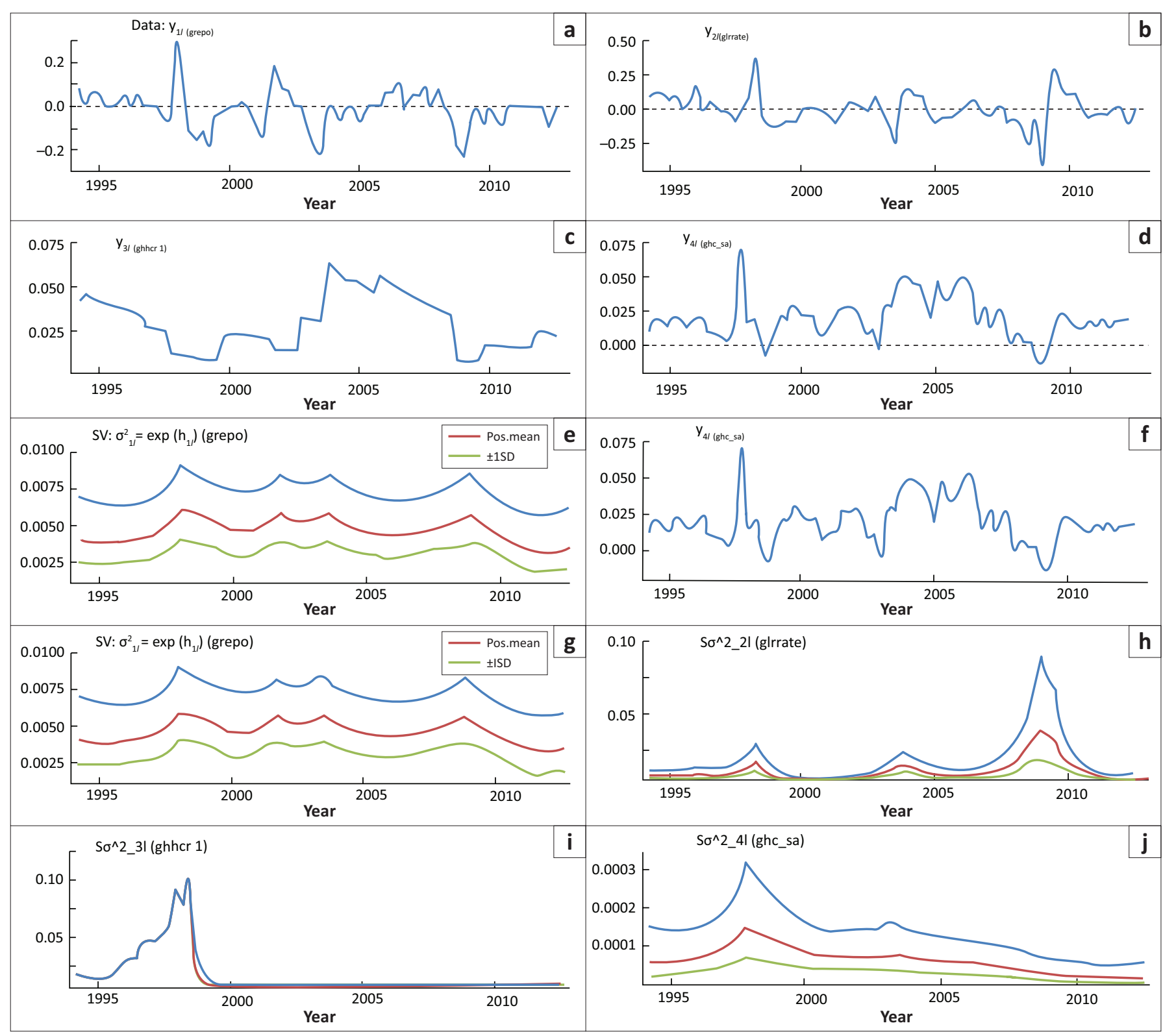

Note: Posterior mean (solid line) and 95\% credible intervals (dotted line).

Source: Owusu-Sekyere, E., 2016, 'The impact of monetary policy on household consumption in South Africa: Evidence from Vector Autoregressive Techniques', Economic Research Southern Africa (ERSA), Working Paper WP/2016/18, viewed 12 May 2016, from https://econrsa.org/system/files/publications/working_papers/working_paper_598.pdf

FIGURE 1: Posterior draws (a-j) for each data series and posterior mean estimates for stochastic volatility of the structural shock.

financial inclusion itself is much broader than just credit extension. Overleveraged household incomes could be measured by household debt to disposable income ratio and unemployment by unemployment rate. We do not control for this in the model directly; however, the extent to which one could acquire credit for consumption is captured by household credit and household consumption, both of which are not possible if one's income is overleveraged, and also require that one is employed in order to be able to acquire credit for debt finance consumption. Thus, these other variables are to some extent indirectly controlled for in the model.

The sample autocorrelation function, the sample paths and posterior densities for the selected parameters are shown in Figure 2.
After discarding the initial (1000) samples in the burn-in period the sample paths look stable and the sample autocorrelations drop smoothly. This indicates that the sampling method efficiently produces samples with low autocorrelation (Nakajima 2011). Figure 3 plots impulse responses of the time-invariant VAR and TVP-VAR models. Figure 3a-f illustrates the constant parameter VAR impulse response functions. Figure 3a-f shows how real lending rate, household credit and household consumption respond to shocks in the repo rate and how the repo rate responds to shocks in itself. Figure 3a-f further shows the response of household consumption to shocks in household credit and conversely the response of household credit to shocks in household consumption. Figure $3 g-j$ details impulse response functions of the TVP-VAR estimation. The time-invariant VAR averages the impulse responses at all points in time 


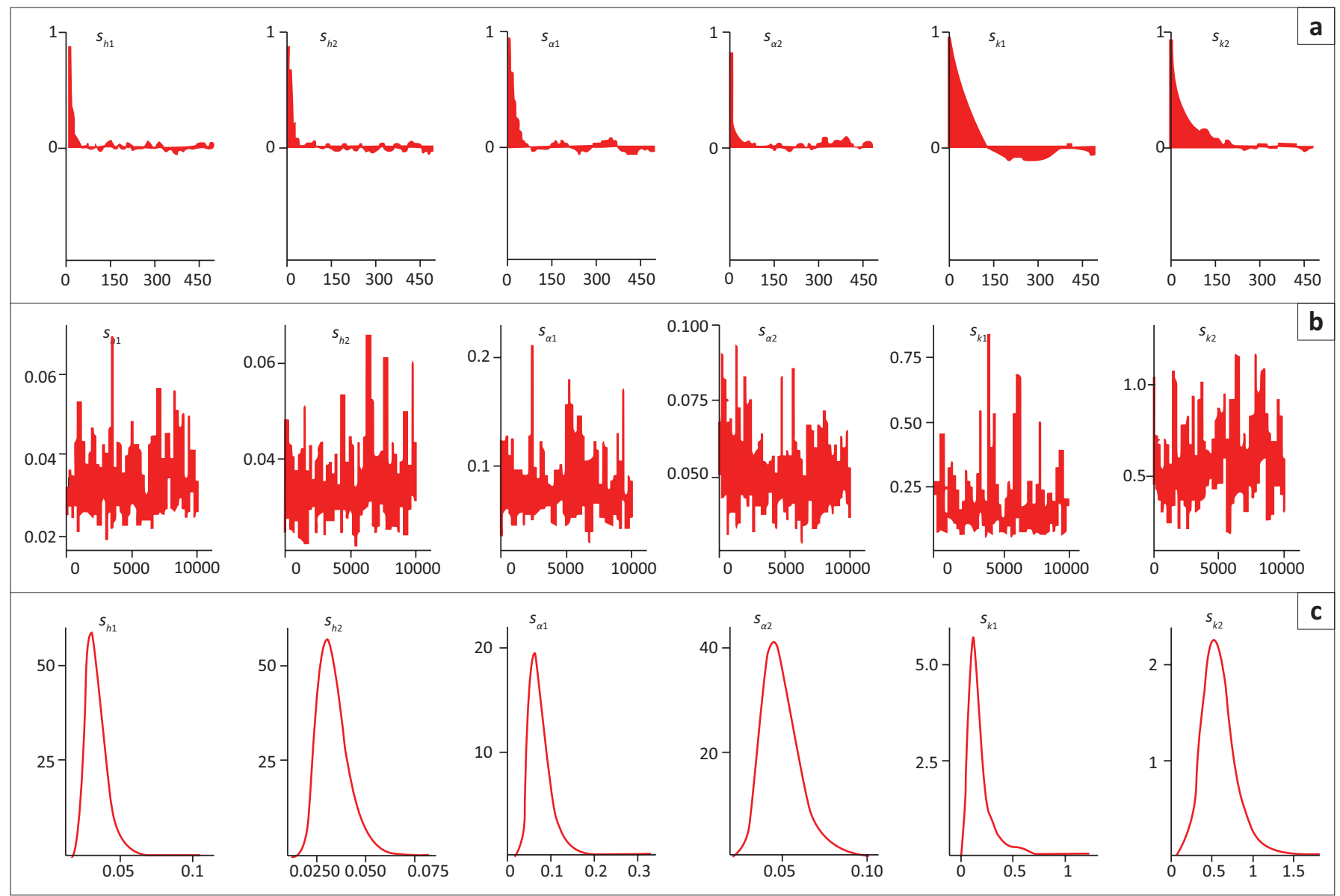

Note: The estimates of $\Sigma$ a and $\Sigma \beta$ are multiplied by 100 .

Source: Owusu-Sekyere, E., 2016, 'The impact of monetary policy on household consumption in South Africa: Evidence from Vector Autoregressive Techniques', Economic Research Southern Africa (ERSA), Working Paper WP/2016/18, viewed 12 May 2016, from https://econrsa.org/system/files/publications/working_papers/working_paper_598.pdf

FIGURE 2: Estimates of the moments and posterior distributions of the model: with (a) sample autocorrelations (b), sample paths and (c) posterior densities.

over the sample period. On the contrary, the impulse responses from the time-varying VAR model show the magnitude of the responses of the TVPs for each selected period - one quarter, two quarters, 1 year and 2 years. As can be observed from Figure $3 \mathrm{a}-\mathrm{f}$, the response of the repo rate to shocks in itself is positively significant till the eighth quarter, after which it dissipates. The real lending rate impulse response follows a trend similar to that of the repo rate. Real lending rate responds contemporaneously to a shock in the repo rate spiking in the first quarter in response to the shock. It then stays significantly positive for the first six quarters after the shock.

Household credit declines steeply one quarter after a repo rate shock, becoming negatively and statistically significant in the second quarter after which it dissipates. Household consumption responds more moderately to a shock in the repo rate with a lag, becomes negative and statistically significant in the third quarter after the shock and declines steadily thereafter.

Both household credit and household consumption respond contemporaneously to a shock in each other, staying positive and statistically significant for most part of the sample period. It implies that although household consumption is credit driven, household credit is also demand driven by household consumption in South Africa.

Figure 3g-j depicts the impulse responses of the TVP-VAR model at different horizons of one quarter, two quarters, four quarters and eight quarters at each point of the sample. The TVP-VAR impulse responses vary more significantly over time as compared to the constant parameter VAR impulse responses. The TVP-VAR impulse response of household credit to a repo rate shock shows a steep decline and greater variability, especially in the short-term, than in the constant parameter VAR impulse responses. The decline in household credit is, however, milder over longer horizons as depicted by the two, four and eight quarters ahead trajectories. Household credit, however, remains largely negative and on a downward trend after the political transition post 1994 to 2000, and after the adoption of inflation targeting in South Africa in 2000. This trend can be observed across all horizons, but is more pronounced in the short-term than over longer horizons. The steep decline in household credit post transition as explained is in reaction to monetary tightening by monetary authorities in South Africa aimed at mitigating the impact of the Asian crisis and the capital flight from South Africa during this period. The further decline in household credit post inflation targeting is also attributable 
to the contractionary monetary policy implemented at the time to stem the vast depreciation of the Rand because of unprecedented capital outflows and dip in portfolio flows to South Africa. We observe a positive response of household credit to a repo rate shock between 2006 and 2008. This is because despite a steady increase in the repo rate from $7 \%$ in 2006Q1 to $12 \%$ in 2008Q3, there was an expansion in household income during this period leading a steady increase in household credit, although households incurred more debt in the process (SARB 2012). This explains the positive response of household credit to the repo shock between 2006 and 2008. The repo rate then declined sharply from $12 \%$ in 2008Q3 to 5\% in 2012Q4, during which household credit stays positive but trends downwards in response to

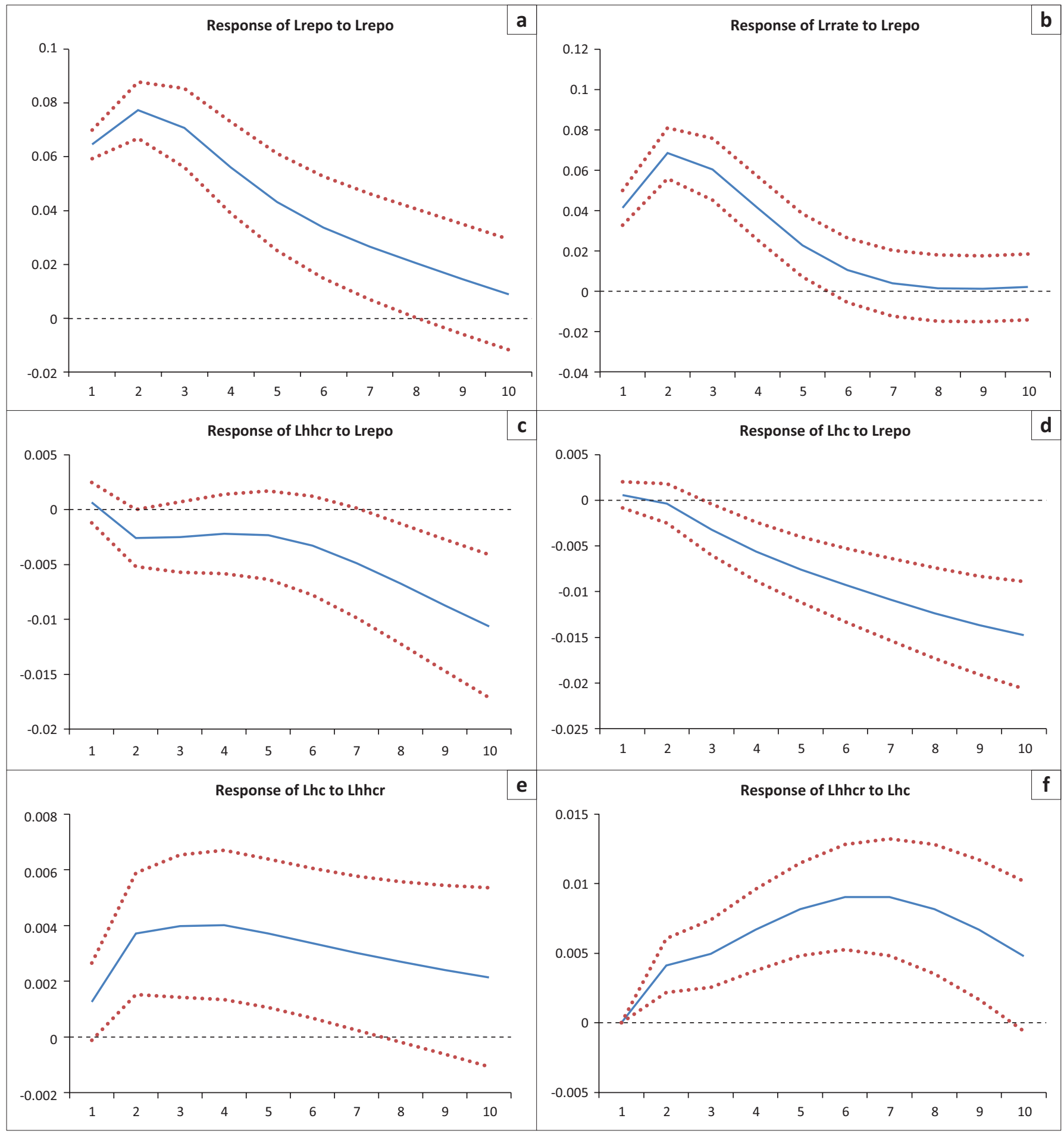

Note: Posterior mean (solid line) and 95\% intervals (dotted line) for the constant VAR model. Time-varying responses for one quarter (red line), two quarters (mauve line), 1 year (deep green line) and 2 years (lemon green line).

Source: Owusu-Sekyere, E., 2016, 'The impact of monetary policy on household consumption in South Africa: Evidence from Vector Autoregressive Techniques', Economic Research Southern Africa (ERSA), Working Paper WP/2016/18, viewed 12 May 2016, from https://econrsa.org/system/files/publications/working_papers/working_paper_598.pdf

FIGURE 3: Impulse response functions of (a-f) constant parameter VAR model and (g-j) Time-varying impulse responses (TVP-VAR) models (repo, rrate, hhcr, hc) to a one standard deviation change in the repo rate. 


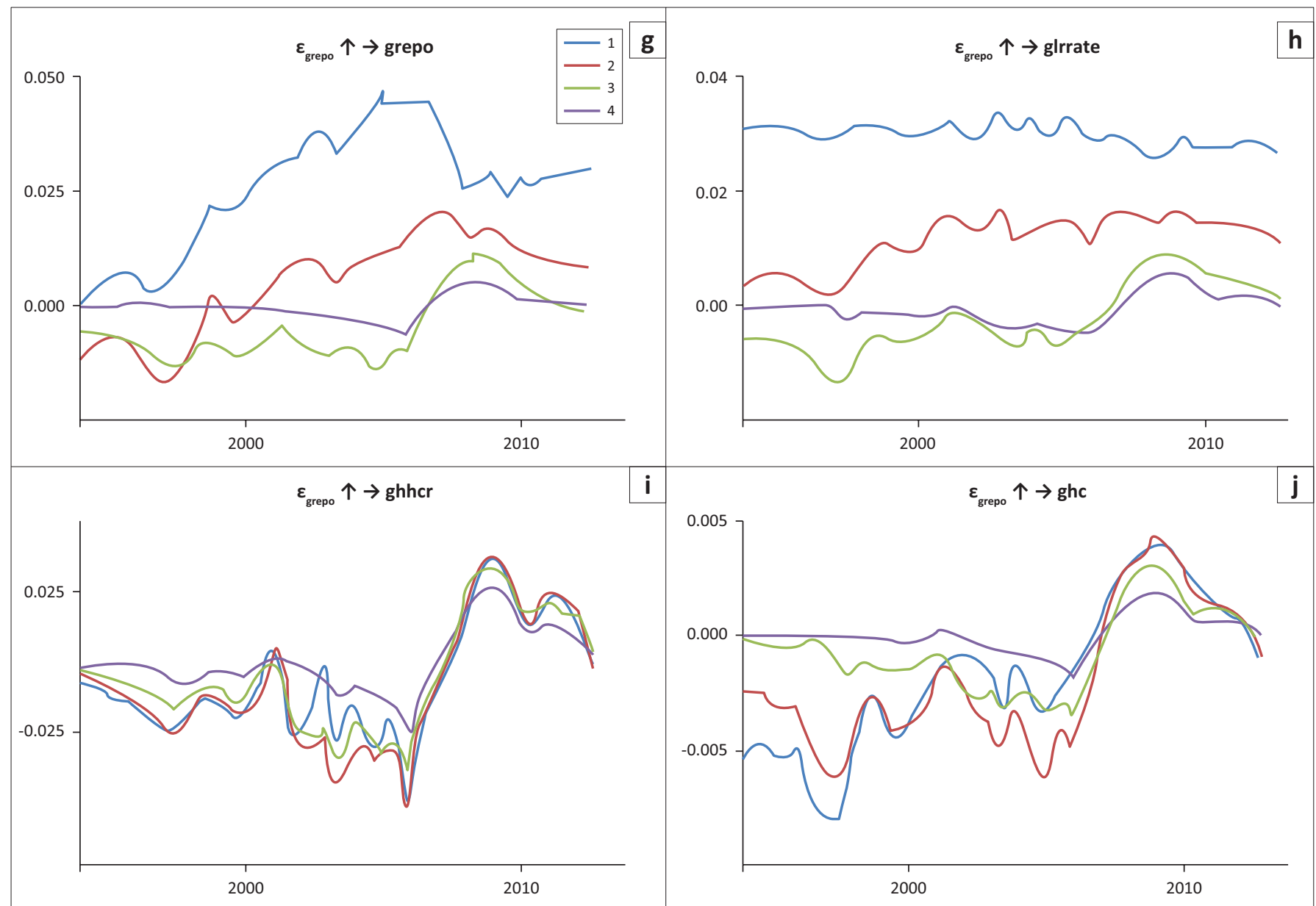

Note: Posterior mean (solid line) and $95 \%$ intervals (dotted line) for the constant VAR model. Time-varying responses for one quarter (red line), two quarters (mauve line), 1 year (deep green line) and 2 years (lemon green line).

Source: Owusu-Sekyere, E., 2016, 'The impact of monetary policy on household consumption in South Africa: Evidence from Vector Autoregressive Techniques', Economic Research Southern Africa (ERSA), Working Paper WP/2016/18, viewed 12 May 2016, from https://econrsa.org/system/files/publications/working_papers/working_paper_598.pdf

FIGURE 3 (Continues...): Impulse response functions of (a-f) constant parameter VAR model and (g-j) Time-varying impulse responses (TVP-VAR) models (repo, rrate, $h h c r, h c)$ to a one standard deviation change in the repo rate.

overleveraged household disposable income (SARB 2014). The TVP-VAR impulse response of household consumption also shows greater variability in the short-term than over longer horizons. Similar to trends in the impulse response of household credit, household consumption stays negative post transition and after inflation targeting, becoming positive after the global financial crisis. It, however, trends downwards approaching zero after 2009. This depicts a close comovement between household credit and household consumption as depicted by the cross-correlation analysis. Additional factors driving the downward trend in household consumption post 2010 were job losses, labour stoppages and falls in household disposable income.

\section{Conclusion and policy implications}

This study set out to investigate the Keynesian interest rate channel of monetary policy transmission in South Africa, focussing on the behaviour of household credit and household consumption. The study focussed on three periods: (1) before inflation targeting (1994-1999), (2) after inflation targeting (2000-2007) and (3) during the global financial crisis (2007-2012) during which different monetary policy stances existed. Constant parameter VAR estimation techniques by Sims (1980) and TVP-VAR with stochastic volatility by Primiceri (2005) were used in this study.

Testing the hypotheses of the traditional Keynesian interest rate channel of monetary transmission, the results show that household credit and consumption declined during periods of monetary contraction - post transition, and post inflation targeting, and increased during periods of monetary expansion - during the global financial crisis. Basically, the hike in the repo rates leads to hikes in short-term interest rates, ceteris paribus, increasing the cost of borrowing for households and worsening existing levels of household debt. The increased cost of borrowing reduces household demand for credit, as households' debt position would also have worsened. This serves as evidence of the cost of credit effect of monetary policy on household consumption in South Africa. The TVP-VAR impulse responses show more detail and greater variability over time in the response of household credit and consumption to a repo rate shock than the constant parameter VAR impulse responses. This variability better captures the impact of structural changes in South Africa and exogenous shocks on monetary policy conduct and its pass through effect on household credit and 
consumption in South Africa. Contrary to the moderate and lagged response of household consumption to a repo rate shock as depicted by the constant parameter VAR, the TVPVAR impulse responses show an immediate steep decline in response to a repo rate shock, especially in the short-term. Longer horizons in the TVP-VAR show milder declines in household credit and consumption to a repo rate shock. This indicates that household credit and household consumption decline more steeply in the short run in response to a monetary tightening in South Africa and decline mildly over longer horizons. The mild decline over longer horizons could be attributed to households adjusting their spending portfolios to the budget constraints generated by the monetary tightening. This study, therefore, concludes that there is a cost of credit effect of monetary policy on household credit and consumption in South Africa strongest in the immediate short-term, one to three quarters after the shock and milder over longer time periods. However, we also see a period of contractionary monetary policy between 2006 and 2008 that still saw a positive relationship between repo rate and household credit and household consumption in South Africa. This is attributable to an increase in household incomes during this period. Again although household credit and household consumption increase during the global financial crisis because of an expansionary monetary policy stance, they increase in a decreasing manner as a result of overleveraged household disposable income. Finally, the TVP-VAR algorithm is superior to the constant parameter VAR in capturing the impact of structural breaks and external shocks on the conduct of monetary policy in South Africa and its pass through effect on household credit and consequently household consumption in South Africa.

In terms of policy implications, the findings of this article show that there are microeconomic effects of changes in macroeconomic policy. Monetary tightening affects households' ability to borrow affordably and further worsens existing household debt, especially as household consumption in South Africa is largely driven by debt. For existing debt portfolios, household debt to disposable income ratio would be worsened by the monetary tightening. In the case of new credit, the declining impact of the monetary tightening on household credit would be strongest in the short-term as depicted by the $1 \mathrm{Q}$ and $2 \mathrm{Q}$ ahead trajectories in the TVPVAR IRFs. This would further worsen already muted household consumption expenditure. There is, therefore, the need to take into consideration the microeconomic effects of macroeconomic policy changes.

On the brighter side, households without overleveraged incomes should be encouraged to save in financial products with attractive yields thereby taking advantage of the higher interest rates to earn higher yields on their investment portfolios. This could help to mitigate household liquidity constraints over time created by the unfavourable macroeconomic outlook expected to pertain in the short to medium term going forward.

In terms of policy implications, the findings of this article show that there are microeconomic effects of changes in macroeconomic policy. Monetary tightening affects households' ability to borrow affordably and further worsens existing household debt, especially as household consumption in South Africa is largely driven by debt. For existing debt portfolios, household debt to disposable income ratio would be worsened by the monetary tightening. In the case of new credit, the declining impact of the monetary tightening on household credit would be strongest in the short-term as depicted by the $1 \mathrm{Q}$ and $2 \mathrm{Q}$ ahead trajectories in the TVP-VAR impulse response functions. This would further worsen already muted household consumption expenditure. There is, therefore, the need to take into consideration the microeconomic effects of macroeconomic policy changes. On the brighter side, households without overleveraged incomes should be encouraged to save in financial products with attractive yields thereby taking advantage of the higher interest rates to earn higher yields on their investment portfolios. This could help to mitigate household liquidity constraints over time created by the unfavourable macroeconomic outlook expected to pertain in the short to medium term going forward.

\section{Acknowledgements}

The author thanks Jouchi Nakajima, the author of the OX software program, for running the TVP-VAR estimation and Prof. Rangan Gupta, Prof. Nicola Viegi and Prof. Renee van Eyden for their useful comments. The usual disclaimer applies.

\section{Competing interests}

The authors declare that they have no financial or personal relationships that may have inappropriately influenced them in writing this article.

\section{References}

Abradu-Otoo, P, Amoah, B. \& Bawumiah, M., 2003, An investigation of the transmission mechanisms of monetary policy in Ghana: A structural vector error correction analysis, Bank of Ghana Working Paper WP/OG-2003/02, viewed 10 February 2017, from https://bog.gov.gh/privatecontent/Publications/Staff_Working.../ 2003/wp-02.pdf

Aron, J. \& Muellbauer, J., 2002, 'Interest rate effects on output: Evidence from GDP forecasting model for South Africa', IMF Working Paper 49, 185-213. November IMF Annual Conference, International Monetary Fund, Washington, DC.

Aye, G., Gupta, R. \& Modise, M., 2013, 'Do stock prices impact consumption and interest rate in South Africa? Evidence from time-varying vector autoregressive model', Journal of Emerging Market Finance 14(2), 176-179. https://doi. org/10.1177/0972652715584267

Banerjee, A. \& Malik, S., 2012, The changing role of expectations in US monetary policy: A new look using the Livingston survey, Working Paper No. 376, Banque De France, Paris.

Bernanke, B.S. \& Gertler, M., 1995, 'Inside the black box: The credit channel of monetary policy transmission', Journal of Economic Perspectives 9(4), 27-48. https://doi.org/10.1257/jep.9.4.27

Black, F., 1976, 'Studies of stock market volatility changes', Proceedings of the American Statistical Association, Business and Economic Statistics Section pp. 177-181, viewed November 2016, from http://www.scirp.org/ (S(351jmbntvnsjt1aadkposzje))/reference/ReferencesPapers.aspx

Cheng, K.C., 2006, A VAR analysis of Kenya's monetary policy transmission mechanism: How does central bank's repo rate affect the economy?, IMF Working Paper WP/06/300, International Monetary Fund, Washington, DC.

Christiano, L.J., Eichenbaum, M. \& Evans, C.L., 1999, 'Monetary policy shocks: What have we learned and to what end?', in J.B. Taylor \& M. Woodford (eds.), Handbook of macroeconomics, vol. 1, pp. 65-148, Elsevier, Amsterdam.

Cogley, T. \& Sargent, T.J., 2001, 'Evolving Post War II U.S. inflation dynamics', NBER Macroeconomics Annual 16, 331-373. https://doi.org/10.1086/654451

Dickey, D.A. \& Fuller, W.A., 1981, 'Likelihood ratio statistics for autoregressive time series with a unit root', Econometrica 49(4), 1057-1072. https://doi.org/ $10.2307 / 1912517$ 
Disyatat, P. \& Vongsinsirikul, P., 2003, 'Monetary policy and the transmission mechanism in Thailand', Journal of Asian Economics 14, 4. https://doi. mechanism in Thailand, Journal of
org/10.1016/S1049-0078(03)00034-4

Duca, J., 1995, Credit availability, Bank consumer lending and consumer durables, Working Paper 95-14, Federal Reserve Bank of Dallas, Dallas, TX.

Du Plessis, S., Smit, B. \& Steinbach, R., 2014, A medium-sized open economy DSGE of South Africa, South African Reserve Bank Working Paper WP/14/04, viewed 15 February 2017, from https://www.resbank.co.za/Lists/News\%20and\%20 Publications/Attachments/6319/WP1404.pdf

Eichenbaum, M., 1992, 'Comments: Interpreting the macroeconomic time serie facts: The effects of monetary policy by Christopher Sims', European Economic Review 36(5), 1001-1011. https://doi.org/10.1016/0014-2921(92)90042-U

Franta, M. Horvath, R. \& Rusnak, M., 2011, Evaluation changes in the monetary transmission mechanism in the Czech Republic, Working Paper Series 13, Czech National Bank, Prague.

Geweke, J., 1992, 'Evaluating the accuracy of sampling-based approaches to the calculation of posterior moments', in J.M. Bernado et al. (eds.), Bayesian Studies, calculation of posterior moments', in J.M. Bernado et al.
vol. 4, pp. 169-188, Oxford University Press, New York.

Ghysels, E., Harvey, A.C. \& Renault, E., 2002, 'Stochastic volatility', in C.R. Rao \& G.S. Maddala (eds.), Statistical methods in finance, pp. 119-199, Elsevier Science, Amsterdam.

Gumata, N., Kabundi, A. \& Ndou, E., 2013, Important channels of transmission of monetary policy shock in South Africa, South African Reserve Bank Working Paper WP/2013/06, South African Reserve Bank, Pretoria.

Kim, S. \& Roubini, N., 2000, 'Exchange rate anomalies in the industrial countries: A solution with a structural VAR approach', Journal of Monetary Economics, pp. 561-568. https://doi.org/10.1016/S0304-3932(00)00010-6

Koop, G. \& Korobilis, D., 2010, 'Bayesian multivariate time series methods fo empirical macroeconomics', Foundations and Trends in Econometrics 2, 267-358.

wiatkowski, D, Phillips, P.C.B., Schmidt, P. \& Shin, Y., 1992, 'Testing the null hypothesis of stationarity against the alternative if a unit root', Journal of Econometrics 54 159-178. https://doi.org/10.1016/0304-4076(92)90104-Y

Mishkin, F.S., 1995, 'Monetary transmission mechanism', Journal of Economic Perspectives 9(4), 3-10. https://doi.org/10.1257/jep.9.4.3

Mishra, P. \& Montiel, P., 2012, How effective is monetary transmission in low-income countries? A survey of the empirical evidence, IMF Working Paper WP/12/143, International Monetary Fund, Washington, DC

Mwabutwa, C., Bittencourt, M. \& Viegi, N., 2013, Evolution of monetary policy transmission mechanism in Malawi. A TVP VAR approach, University of Pretoria Working Paper 2013-27, University of Pretoria, Pretoria.

Nakajima, J., 2011, 'Time-varying parameter VAR model with stochastic volatility: An overview of methodology and empirical applications', Monetary and Economic Studies 29, 107-142.

Owusu-Sekyere, E., 2016, 'The impact of monetary policy on household consumption in South Africa: Evidence from Vector Autoregressive Techniques', Economic Research Southern Africa (ERSA), Working Paper WP/2016/18, viewed 12 May 2016, from https://econrsa.org/system/files/publications/working_papers/working paper_598.pdf
Peretti, V., Gupta, R. \& Inglesi-Lotz, R., 2012, 'Do house prices impact consumption and interest rate in South Africa? Evidence from a time-varying vector autoregressive model', Economics, Management and Financial Markets 7(4), 101-120.

Phillips, P.C.B. \& Perron, P., 1988, 'Testing for a unit root in time series regression', Biometrika 75, 335-346. https://doi.org/10.1093/biomet/75.2.335

Primiceri, G.E., 2005, 'Time varying structural vector autoregressions and monetary policy', Review of Economic Studies 72(3), 821-852. https://doi. org/10.1111/j.1467-937X.2005.00353.x

Saxegaard, M., 2006, Excess liquidity and the effectiveness of monetary policy: Evidence from sub-Saharan Africa, IMF Working Paper No. 06/115, International Monetary Fund, Washington, DC.

Shephard, N., 2005, Stochastic volatility: Selected readings, Oxford University Press, Oxford.

Sims, C.A., 1980, 'Macroeconomics and reality', Econometrica 48(1), 1-48. https:// doi.org/10.2307/1912017

Smal, M.M. \& De Jager, S., 2001, The monetary transmission mechanism in South Africa, South African Reserve Bank Working Paper WP/2001/16, viewed 20 November 2016, from www.resbank.co.za

South African Reserve Bank (SARB), 1998, Quarterly bulletin, South African Reserve Bank, Pretoria, South Africa.

South African Reserve Bank (SARB), 1999, Quarterly bulletin, South African Reserve Bank, Pretoria, South Africa.

South African Reserve Bank (SARB), 2002, Quarterly bulletin, South African Reserve Bank, Pretoria, South Africa.

South African Reserve Bank (SARB), 2004, Quarterly bulletin, South African Reserve Bank, Pretoria, South Africa.

South African Reserve Bank (SARB), 2009, Quarterly bulletin, South African Reserve Bank, Pretoria, South Africa.

South African Reserve Bank (SARB), 2012, Quarterly bulletin, South African Reserve Bank, Pretoria, South Africa.

South African Reserve Bank (SARB), 2013, Quarterly bulletin, South African Reserve Bank, Pretoria, South Africa.

South African Reserve Bank (SARB), 2014, Quarterly bulletin, South African Reserve Bank, Pretoria, South Africa.

South African Reserve Bank (SARB), 2015, Quarterly bulletin, South African Reserve Bank, Pretoria, South Africa.

The International Monetary Fund, n.d., International Financial Statistics of the International Monetary Fund, viewed 12 May 2016, from http://www.imf.org/ external/

Uhlig, H., 1997, 'Bayesian vector autoregressions with stochastic volatility', Econometrica 65(1), 59-73. https://doi.org/10.2307/2171813

Wilcox, J., 1990, 'Nominal interest rate effects on real consumer expenditure', Business Economics 25(4), 31-37. 


\section{Appendix 1}

TABLE 1-A1: Sources and definitions of variables.

\begin{tabular}{|c|c|c|c|}
\hline Symbol & Variable & Source & Definition \\
\hline repo & Repo rate & SARB & South African Reserve Bank accommodation - repurchase rate (\%) \\
\hline rrate & Real lending rate & SARB & Nominal lending rate less the rate of inflation (consumer price index annual percentage change) \\
\hline hher & $\begin{array}{l}\text { Domestic credit to } \\
\text { households }\end{array}$ & SARB & Loans and advances to households by all monetary institutions \\
\hline hc & $\begin{array}{l}\text { Aggregate household } \\
\text { consumption }\end{array}$ & SARB & $\begin{array}{l}\text { Final consumption expenditure by households - Total personal consumption expenditure (PCE) seasonally adjusted in } 2005 \text { constant } \\
\text { prices ( } \mathrm{R} \text { million) }\end{array}$ \\
\hline oil & World oil price index & SARB & Brent crude oil price in US dollars; index \\
\hline wages & Wage index & SARB & Nominal unit labour cost index \\
\hline
\end{tabular}

repo, South African Reserve Bank accommodation - repurchase rate (\%); rrate, Nominal lending rate less the rate of inflation (consumer price index annual percentage change); hhcr, Loans and advances to households by all monetary institutions; hc, Final consumption expenditure by households - Total personal consumption expenditure (PCE) seasonally adjusted in 2005 constant prices (R million); oil, Brent crude oil price in US dollars index; comm, Non-fuel world market prices and unit values: all commodities; wages, Nominal unit labour cost index; SARB, South African Reserve Bank; IMF, International Monetary Fund; IFS, International Financial Statistics.

Source: Please see the full reference list of the article, Owusu-Sekyere, E., 2017, 'The impact of monetary policy on household consumption in South Africa: Evidence from vector autoregressive techniques', South African Journal of Economic and Management Sciences 20(1), a1660. https://doi.org/10.4102/sajems.v20i1.1660, for more information

TABLE 2-A1: Order of integration of the variables.

\begin{tabular}{|c|c|c|c|c|c|c|}
\hline \multirow[t]{2}{*}{ Variables } & \multicolumn{2}{|c|}{ ADF } & \multicolumn{2}{|c|}{ PP } & \multicolumn{2}{|c|}{ KPSS } \\
\hline & Levels & Differenced & Level & Differenced & Level & Differenced \\
\hline repo & -1.56 & $-5.96 * * *$ & -0.75 & $-42.68 * * *$ & 23.57 & $0.40 * * *$ \\
\hline rrate & -0.75 & $-5.60 * * *$ & -0.69 & $-6.05 * * *$ & 0.81 & $0.09 *$ \\
\hline hhor & 1.19 & $-0.87^{*}$ & 2.64 & $-0.87^{*}$ & 13.17 & $0.73 * * *$ \\
\hline$h c$ & 0.60 & $-2.88^{*}$ & -1.77 & $-39.71 * * *$ & 1.16 & $0.18^{*}$ \\
\hline oil & -0.34 & $-8.02 * * *$ & -0.07 & $-7.45 * * *$ & 1.08 & $0.22 *$ \\
\hline comm & -0.37 & $-7.58 * * *$ & -0.28 & $-6.24 * * *$ & 1.03 & $-0.18 *$ \\
\hline wages & 1.60 & $-9.24 * * *$ & -0.28 & $-9.24 * * *$ & 1.03 & $-0.56 * * *$ \\
\hline
\end{tabular}

ADF, Augmented Dickey Fuller (1981) Test; PP, Phillip-Perron (1988) Test; KPSS, Kwiatkowski, Phillips, Schmidt-Shin (KPSS) (1992); repo, South African Reserve Bank accommodation - repurchase rate (\%); rrate, Nominal lending rate less the rate of inflation (consumer price index annual percentage change); hhcr, Loans and advances to households by all monetary institutions; hc, Final consumption expenditure by households - Total personal consumption expenditure (PCE) seasonally adjusted in 2005 constant prices (R million); oil, , Brent crude oil price in US dollars index; comm, Non-fuel world market prices and unit values: all commodities; wages, Nominal unit labour cost index.

***/**/* denote $1 \%, 5 \%$ and $10 \%$ levels of significance, respectively. Statistical significance denotes rejection of the null of non-stationarity of the variable in the ADF and PP tests. In the KPSS test, statistical significance denotes failure to reject the null of stationarity.

Note: Augmented Dickey-Fuller (1981) ADF test, Phillips-Perron (1988) PP test both with a $H_{0}$ : non-stationarity, and the Kwiatkowski, Phillips, Schmidt-Shin (KPSS) (1992) with a $H_{0}$ : of stationarity.

TABLE 3-A1: Data properties.

\begin{tabular}{|c|c|c|c|c|c|c|c|c|c|c|c|c|}
\hline \multirow[t]{2}{*}{ Descriptive statistics } & \multicolumn{3}{|c|}{ repo } & \multicolumn{3}{|c|}{ rrate } & \multicolumn{3}{|c|}{ hhcr } & \multicolumn{3}{|c|}{$h c$} \\
\hline & P1 & $\mathbf{P 2}$ & P3 & P1 & P2 & P3 & P1 & P2 & P3 & P1 & $\mathbf{P 2}$ & P3 \\
\hline Mean & 15.5 & 9.8 & 7.7 & 11 & 8 & 4.6 & 21.6 & 42.4 & 104.4 & 11.8 & 19.3 & 32.9 \\
\hline Maximum & 21.9 & 13.5 & 12 & 17.7 & 9.6 & 7.2 & 26.4 & 72.6 & 129.1 & 16.4 & 34.9 & 44.0 \\
\hline Minimum & 12 & 7 & 5 & 5.7 & 6 & 2.3 & 16.1 & 27.6 & 76.1 & 8.7 & 12.4 & 26.4 \\
\hline Std. Dev & 2.6 & 2.3 & 2.4 & 3 & 0.96 & 1.4 & 36.8 & 13.8 & 14.4 & 2.0 & 5.4 & 4.7 \\
\hline
\end{tabular}

repo, South African Reserve Bank accommodation - repurchase rate (\%); rrate, Nominal lending rate less the rate of inflation (consumer price index annual percentage change); hhcr, Loans and advances to households by all monetary institutions; $h c$, Final consumption expenditure by households - Total personal consumption expenditure (PCE) seasonally adjusted in 2005 constant prices (R million).

Note: P1, post political transition (1994-1999); P2, inflation targeting (2000-2006); P3, crisis (2007-2012).

TABLE 4-A1: Correlation matrix (1994Q1-1999Q4).

\begin{tabular}{lllcc}
\hline Variables & repo & rrate & hhcr & hc \\
\hline repo & 1.00 & - & - & - \\
rrate & $0.80^{* * *}$ & 1.00 & - & - \\
$h h c r$ & $0.43^{* *}$ & $0.75^{* * *}$ & 1.00 & - \\
hc & 0.19 & $0.42^{* *}$ & $0.59^{* * *}$ & 1.00 \\
\hline
\end{tabular}

repo, South African Reserve Bank accommodation - repurchase rate (\%); rrate, Nominal lending rate less the rate of inflation (consumer price index annual percentage change); $h h_{c r}$, Loans and advances to households by all monetary institutions; $h c$, Final consumption expenditure by househol

$* * * / * * / *$ denote $1 \%, 5 \%$ and $10 \%$ levels of significance, respectively.
TABLE 5-A1: Correlation matrix (2000Q1-2006Q4).

\begin{tabular}{llccc}
\hline Variables & repo & rrate & hhcr & hc \\
\hline repo & 1.00 & - & - & - \\
rrate & $0.43^{* *}$ & 1.00 & - & - \\
$h h c r$ & $-0.72^{* * *}$ & $-0.45^{* *}$ & 1.00 & - \\
$h c$ & $-0.61 * * *$ & $-0.41^{* *}$ & $0.88^{* * *}$ & 1.00 \\
\hline
\end{tabular}

repo, South African Reserve Bank accommodation - repurchase rate (\%); rrate, Nominal lending rate less the rate of inflation (consumer price index annual percentage change): $h h c_{\text {, }}$ Loans and advances to households by all monetary institutions; $h c$, Final consumption expenditure by households - Total personal consumption expenditure (PCE) seasonally adjusted in 2005 constant prices ( $R$ million).

$* * * / * * / *$ denote $1 \%, 5 \%$ and $10 \%$ levels of significance, respectively. 
TABLE 6-A1: Correlation matrix (2007Q1-2012Q4).

\begin{tabular}{|c|c|c|c|c|}
\hline Variables & repo & rrate & hhor & $h c$ \\
\hline repo & 1.00 & - & - & - \\
\hline rrate & $0.54 * * *$ & 1.00 & - & - \\
\hline hhor & $-0.82 * * *$ & $-0.65 * * *$ & 1.00 & - \\
\hline$h c$ & -0.30 & -0.17 & $0.47 * *$ & 1.00 \\
\hline
\end{tabular}

repo, South African Reserve Bank accommodation - repurchase rate (\%); rrate, Nominal lending rate less the rate of inflation (consumer price index annual percentage change); hhcr, Loans and advances to households by all monetary institutions; $h c$, Final consumption expenditure by households - Total personal consumption expenditure (PCE) seasonally adjusted in 2005 constant prices (R million).

$* * * / * * / *$ denote $1 \%, 5 \%$ and $10 \%$ levels of significance, respectively.

TABLE 7-A1: Lag order selection criteria.

\begin{tabular}{|c|c|c|c|c|c|c|}
\hline Lag & Log $L$ & LR & FPE & AIC & SC & $\mathrm{HQ}$ \\
\hline 0 & 231.9179 & NA & $2.46 \mathrm{e}-08$ & -6.169083 & -5.655142 & -5.964940 \\
\hline 1 & 603.1350 & 657.5845 & $9.66 \mathrm{e}-13$ & -16.31814 & -15.29026 & -15.90985 \\
\hline 2 & 669.8929 & 110.6274 & $2.29 \mathrm{e}-13$ & -17.76837 & $-16.22654^{*}$ & $-17.15594^{*}$ \\
\hline 3 & 689.2536 & 29.87090 & $2.12 \mathrm{e}-13$ & -17.86439 & -15.80862 & -17.04781 \\
\hline 4 & 706.2249 & 24.24462 & $2.13 e-13$ & -17.89214 & -15.32243 & -16.87142 \\
\hline 5 & 732.0302 & $33.91553^{*}$ & $1.69 \mathrm{e}-13^{*}$ & $-18.17229^{*}$ & -15.08864 & -16.94743 \\
\hline 6 & 747.7615 & 18.87755 & $1.83 e-13$ & -18.16461 & -14.56702 & -16.73561 \\
\hline
\end{tabular}

*, indicates lag order selected by the criterion.

LR, sequential modified LR test statistic (at $5 \%$ level); FPE, final prediction error; AIC, Akaike Information Criterion; SC, Schwarz Information Criterion; HQ, Hannan-Quinn Criterion.

TABLE 8-A1: Autoregressive root test for stability of the vector autoregressive (2) model.

\begin{tabular}{ll}
\hline Root & Modulus \\
\hline $0.921365-0.179230 i$ & 0.938636 \\
$0.921365+0.179230 i$ & 0.938636 \\
0.918522 & 0.918522 \\
0.799798 & 0.799798 \\
0.568863 & 0.568863 \\
$0.402986-0.383534 \mathrm{i}$ & 0.556324 \\
$0.402986+0.383534 \mathrm{i}$ & 0.556324 \\
-0.181174 & 0.181174 \\
\hline
\end{tabular}

Note: No root lies outside the unit circle and VAR satisfies the stability condition.

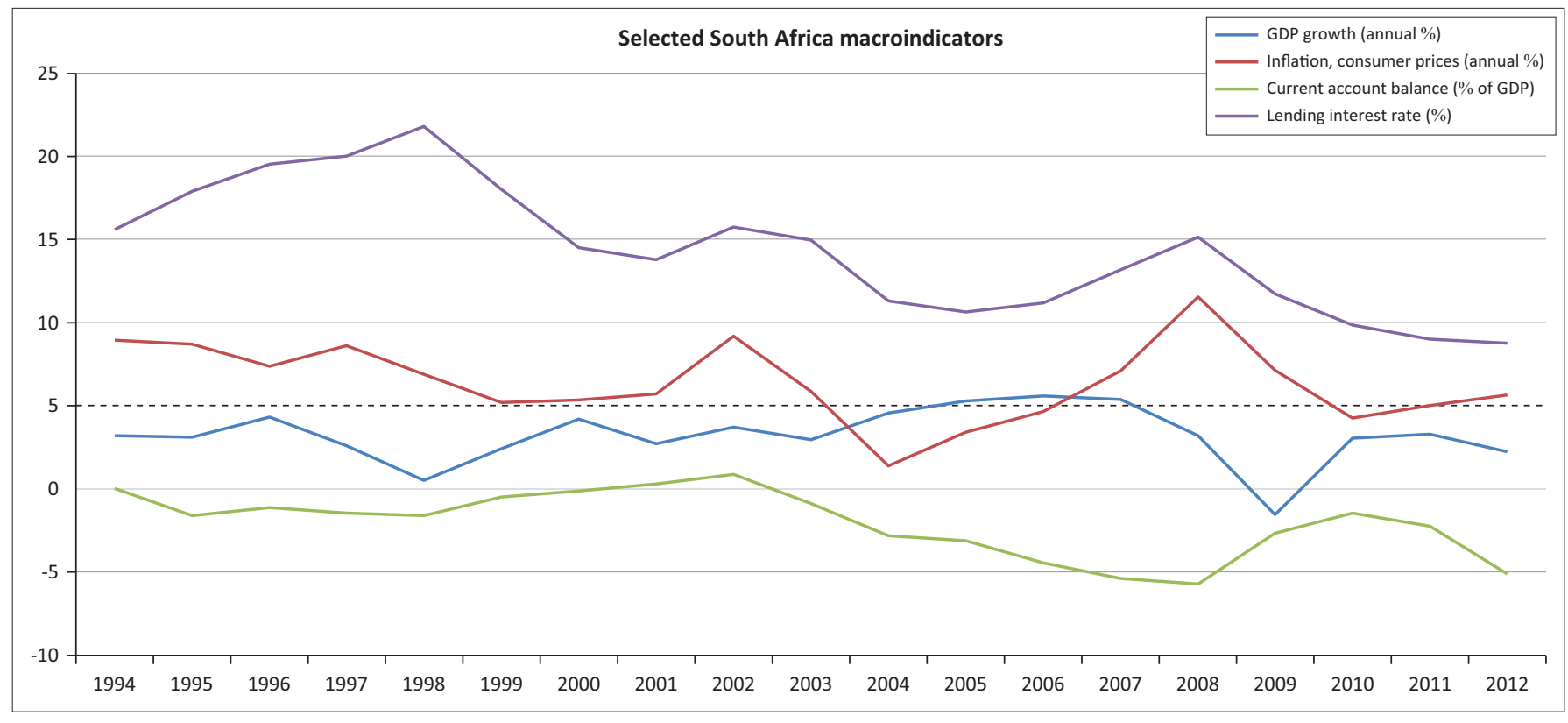

FIGURE 1-A1: Trends in selected South African macroeconomic indicators. 